\title{
An early story of Kho Ping Hoo
}

\author{
C. W. WATSON
}

\begin{abstract}
Kho Ping Hoo (1926-1994) is the most well-known of all Indonesian writers of popular silat stories, largely set in China, which describe the adventures and romances of legendary heroes famed for their skill in martial arts. It is less well-known that he began his career writing critical stories about socioeconomic conditions in the late 50s and early 60s. This paper discusses one of these stories. It places the story in the context of political developments of the time, in particular as they affected the Chinese Indonesian community. The paper argues that this story and one or two others like it come at the end of a tradition of Sino-Indonesian literature which had flourished from the end of the nineteenth century until the mid-1950s. After 1960, Chinese-Indonesian writers cease writing realist fiction of any kind and write either silat stories or romantic stories set in middle class urban environments.
\end{abstract}

KeYwORDS

Kho Ping Hoo; Sino-Indonesian literature; Peranakan; Indonesian literature in the 1950s; social realism; assimilationism.

\section{INTRODUCTION}

The first name that comes to the mind of any Indonesian reader in a discussion of silat or kung fu - martial arts - fiction is Kho Ping Hoo (KPH). As Myra Sidharta indicates in her informative article about KPH (1994) he was exceptionally prolific, writing hundreds of such stories from circa 1963 to his death in 1994. His stories, serialized in newspapers and then published in small multi-volume editions, were read throughout Indonesia and circulated widely in lending libraries and roadside bookstalls. At the height of their popularity around 1974 they were printed in editions of 15,000 copies, a very high print run for Indonesia, but this number declined to 5000 in 1994 (Sidharta 1994: 158) as a consequence, perhaps, of the spread of access to television which

C.W. WATSON teaches anthropology and philosophy at the School of Business and Management of the Bandung Institute of Technology (ITB) and is an Emeritus Professor in Social Anthropology of the University of Kent in England. He has a long-standing interest in modern Indonesian literature and Indonesian autobiography. Most of his anthropological research concerns Kerinci in the province of Jambi. Among his publications are Of self and injustice (Leiden: KITLV Press, 2006) and Multiculturalism (Buckingham: Open University Press, 2000). C.W. Watson can be contacted at: bill.watson@sbm-itb.ac.id.

(C) 2017 Faculty of Humanities, Universitas Indonesia

C.W. WATSON | DOI: 10.17510/wacana.v18i2.595. 
has in general led to a decline in reading habits in Indonesia.

Sidharta's article gives a comprehensive account of KPH's life and works and there is no need to repeat what she says there. However, what I want to do in this short account is to draw attention to some early stories of KPH which are very different from what he later came to write and the content of which will come as a surprise to anyone who knows him only as a writer of silat fiction. These early stories were very much of their time and, as we shall see below, mark the end of a particular tradition of Sino-Malay writing. In terms both of their content, then, and the conditions of publication they offer us a glimpse into how some sections of the Indonesian Chinese community positioned themselves within Indonesian politics and society of the time.

In the list of KPH's publications appended to Sidharta's article his first publications are recorded, following Salmon (Sidharta 1994: 162 referring to Salmon 1981), as being in the short story collection Pertemuan said to have been published in 1950 in Tasikmalaya by the publisher Djelita. This is a mistake. In the printed book there is no date of publication, but internal evidence makes it clear that the book must have been published some time after 1959. There is, for example, a reference to a 1956 Dodge car (Pertemuan 1961: 22); furthermore, in another story there is a reference to Manipol Usdek (Pertemuan 1961: 66) which puts the story after 1960. It seems therefore that the book was published some time between 1960-1963 when KPH left Tasik.

A further confusion in Myra's list is that Pertemuan is described as only containing three of KPH's stories: "Sosiawan besar", "Penggosok sepatu" and "Riwajat Pak Kecil". In fact, there is a fourth story "Buruh dan Tahun Baru" (Pertemuan 1961: 29-35). Of these four stories, two, "Penggosok" and "Buruh dan Tahun Baru" were also published elsewhere, "Penggosok" in Liberty (1961) and "Buruh" - under the title "Buruh dan Sintjhia" - in Star Weekly (1959) (Sidharta 1994: 169).

A few words about the appearance of the volume will help readers to get a clearer understanding of conditions of Indonesian publications at the time. Pertemuan (see Picture 1) was published in Tasikmalaya and printed the Havid printing press. It consists of 80 pages on cheap paper and sold for Rp 25 ,- at the time. In addition to KPH's stories the book contains three stories by Ns. Kuntoro: "Mentjari ilham", "Hadiah Lebaran", "Jang datang kembali"; one by Tjoe Beng Siang, "Gagal"; two by Chen Chen A, "Budi", and "Siasat si Lennie"; and one by T. B. Setyadi, "Sebuah surprise". There is no way of telling whether Ns. Kuntoro and T.B. Setyadi are Chinese-Indonesians or not since they may be Chinese who adopted Indonesian names - see below. On the other hand, it is perfectly plausible that they are non-Chinese Indonesians. There are several good ink-drawings in the book introducing some of the stories, but there is no indication who the artist was. 

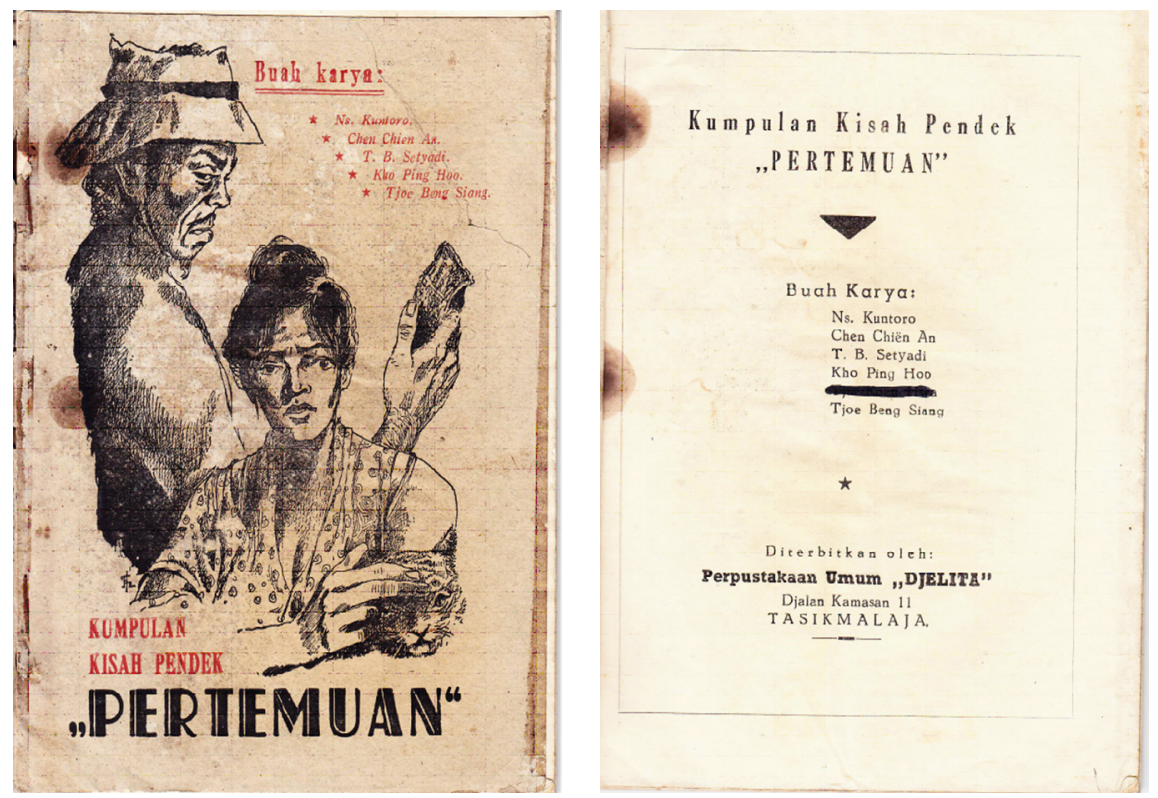

Picture 1. The front cover of the short stories collection "Pertemuan (n.d.)" (left) and the title page (right).

Irrespective, however, of which of KPH's short stories was the first to be published and where, these stories which came from his pen during the 1950s deserve attention since they are so markedly different from what he later came to write and yet at the same time illustrate the transition which Chinese Indonesian ${ }^{1}$ literature was going through at the time, as other writers have commented. ${ }^{2}$ The movement is in the first place a shift from the essentially romantic fiction, with predominantly Chinese Indonesians (Peranakan) as central characters, popular in the years just before the Pacific War, to a more realistic fiction where Chinese ethnicity is rarely mentioned, to the emergence of two new, very different, strands of Chinese-Indonesian writing, a new cosmopolitan romantic literature and a re-emergence of silat fiction from the mid-seventies onwards. But this is to anticipate and some historical context needs mentioning so that we can understand how and why this development occurred.

1 I use the term Chinese Indonesian throughout to refer to all those of Chinese ethnic origin living in Indonesia. The usage is intended to parallel American usage when referring to, for example, Italian Americans or Polish Americans.

2 Salmon (1992: 4) writes "Toutefois, certains auteurs qu'il aurait été bon de pouvoir étudier ici, tel que Kho Ping Hoo [...] ont suivi un parcours sensiblement different et apres avoir écrit des nouvelles dans les années 1950, sont ultérieurment revenus à un silat rénové [...]", and this is echoed by Kratz (1992: 145) “[A]mong the writers now [1970s and 1980s] emerging before a wider public were names last heard of in the late 1950s when the stalwarts of Peranakan culture pinned their hopes on Kho Ping Hoo and others who even in their twenties and thirties still crowded the youth and cultural pages of the Peranakan journals of those days". 


\section{SOME HISTORICAL CONTEXT ${ }^{3}$}

The 50s and early 60s were a difficult time for many Indonesian Chinese. Under various governments of the new Republic of Indonesia they were subject to considerable political pressure, especially from those nationalistinspired governments of Indonesia who wanted to push them out of economic sectors in which they were dominant and replace them with indigenous entrepreneurs. There were also suspicions of their loyalty to the new Republic, since some Indonesian Chinese, by no means all, had sided with the Dutch in the revolutionary period between 1945-1950.

In fact, the loyalties of the Chinese community were split, although such a split was not obviously visible to the man in the Indonesian street who classified them all under the category of Chinese. The Chinese themselves drew a sharp distinction at the time, one which became less conspicuous from the late 60s onwards, between the Peranakan Chinese those Chinese who had settled in Indonesian at least three or four generations previously and who had more or less lost contact with their Chinese antecedents, and the totok, of only one or two generations residence who still retained their Chinese associations and links and were able to speak Chinese - usually a Hokkien dialect. Among the former there were further class divisions between the wealthy, usually Dutch-speaking, Peranakan, often known as the kaum Packard, because of their possession of luxury Packard cars, who worked closely with Dutch commerce and trade and those who were employed in petty trading or menial labour. KPH, as described by Sidartha (1994:160) was a Peranakan of the latter class. A good example of wealthy Peranakan of the same period who like KPH was also from an east Javanese family was KPH's near contemporary, the historian, Onghokham.

One particular pressure on the Chinese in the 1940s and 1950s was for them to declare where their national loyalties lay, which meant opting definitively for Indonesian or Chinese citizenship. This caused considerable soul-searching among many Chinese and even those Peranakan who were strongly committed to being Indonesian began to reconsider, or at least look again at, their Chinese traditions and heritage, especially in the light of what appeared to be growing resentment on the part of many indigenous Indonesians. ${ }^{4}$ The upshot of these reflections within the community was the emergence of three distinctive outlooks among the Chinese. The first group opted to declare themselves,

\footnotetext{
3 The brief description here is very schematic and misses many of the nuances of the divisions within the Chinese community of those years, not least of which is the divisions between those oriented to Taiwan and those who were drawn to the Republic of China. It is intended only to give a necessary historical context to the position of KPH in the 50s and early 60s. There are several books and articles dealing with the history of the Chinese at that period which the interested reader can turn to for further information, including Coppel (1983); Somers (1964); Somers Heidhues (1988); Siauw Giok Tjhan (1982); Cushman and Wang (1988).

4 A classic tragic instance of this is the left wing politician Liem Koen Hian who had fought strenuously for Indonesia in the revolutionary period and felt that after independence he had been rejected by his fellow Indonesians. The strong resentment which he felt led him to give up Indonesian citizenship and opt for Chinese citizenship (Suryadinata 1983).
} 
or, by default in not taking action to the contrary after the nationality law of 1955, allowing themselves, to be classed as Chinese or stateless citizens, and among these many, especially after increasing tension and pressure on them, decided with the rather half-hearted support of the Chinese government, as a consequence of anti-Chinese riots in 1959 to repatriate to China. The second group, inspired by the advocacy of the wealthy Chinese, both Peranakan and totok, who campaigned for a dissolution of Chinese identity and a commitment to the melting pot of Indonesia, with a consequent rejection of Chineseness, especially as that related to contemporary Communist China, became known as assimilationists. Conspicuous among their proposals was a strong recommendation to Chinese to change their names from Chinese or Anglicized ones to Indonesian-sounding, usually Sanskritised, names, thus making themselves less visible to indigenous Indonesians. Many of this group of assimilationists were Christians and were members of Christian political parties both Catholic and Protestant. They leaned politically to the right and were hostile to Soekarno's increasing sympathies to the anti-American bloc in the Cold War of the time.

Opposed to them were the third group the integrationists, those who argued that they were fully committed to Indonesia and to being good Indonesian citizens, but they saw no need to abandon their Chinese heritage or their Chinese names. They saw themselves as simply another ethnic group within the kaleidoscope of Indonesian diversity and like other groups that were proud of, and wanted to retain, their sense of unique identity within the polity; they wanted to be recognised as HoaKiao, overseas Chinese, ethnically Chinese but full citizens of Indonesia (Siauw Giok Tjhan 1981, 1982). Many of them were Dutch-educated Peranakan. Politically, they were on the left and were strong supporters of Soekarno. They were represented in the quasipolitical organization, Baperki, and their most well-known representative was Siauw Giok Tjan. ${ }^{5}$ They also established the Universitas Res Publika, a leading university of the period - later to become, after 1966, Universitas Trisakti - and the newspaper in which they voiced their opinions was Bintang Timor (Somers 1964).

The issues which divided the groups were clear and turned largely on political rather than cultural issues, but because certain individuals themselves often felt that a particular cultural position did not necessarily commit them to the political stance of either one group or another there was considerable ambivalence in their political stance. For example, Onghokham was a strong assimilationist and expressed his belief that Chinese Indonesians should not try to maintain or revive their Chinese heritage, but should instead commit themselves to being Indonesians (Onghokham 1970). An extreme instance of his rejection of Chineseness was his refusal to acknowledge Chinese New Year greetings. However, he did not change his name, his only concession being to combine all three parts of it into one. In line with his sympathies he wrote frequently for the weekly, Star Weekly, the principal organ of assimilationist

5 There is a good analysis of Siauw's position in H. Junus Jahja (2002). 
opinion. At the same time, however, it was clear that his political sympathies were not right-wing or anti-Soekarno (Somers Heidhues 2007: 232) and in fact he later moved away from the assimilationist position of the Lembaga Pembinaan Kesatuan Bangsa (LPKB) which, as described by Thee (2007: 303), he had helped to establish.

Another person who wrote occasionally for Star Weekly was Pramoedya Ananta Toer, not of course a Chinese but one who was sympathetic to their political plight at the time. Pramoedya, however, was very much a man of the left and wrote regularly for Bintang Timur, contributing substantially to its weekly supplement Lentera which, among other causes it espoused, championed the recognition of the role that Indonesian Chinese had played in the birth of modern Indonesian literature.

Pramoedya had been very impressed by visits he made to China in 1956 and 1958 (Hong 2011: 234-266) and subsequently wrote a book entitled Hoa Kiau di Indonesia in which he spoke out for the integrationist cause. The publication of the book led to his imprisonment for a year in 1960-1961. This would appear to be anomalous given the political situation; after all, Baperki and the integrationists were close to the Soekarno and the government of the time. To explain how he came to be arrested requires an understanding of the complexity of the political situation at the time. Although Soekarno and the left-leaning government he was in charge of during the period known as Guided Democracy were in fact moving out of the Soviet orbit and ever closer to China, the military were on the whole extremely hostile to this move, and saw both a long-term threat to national security and an undermining of their own position as defenders of the nation and a power in their own right. There was also a link between some influential military figures and leading assimilationists. Consequently, there seem to have been several attempts to subvert pro-Chinese government policy, by, for example, encouraging and supporting student anti-Chinese demonstrations. Pramoedya's arrest should therefore be seen in the context of this manoeuvring.

The late 50s and early 60s, then, was a time of considerable tensions in which intellectuals and writers of fiction were taking sharply opposed sides. The Chinese-Indonesians, as much as, if not more than any other group, political party or followers of a religious persuasion, were very much subject to the pressures and uncertainties of the time, as historians of the period have described in some detail. Any understanding of positions taken by Peranakan and totok figures of the time needs to be placed firmly in this context. Before, however, locating KPH and his stories within the maelstrom of the times, in addition to referring to the politics of the period we need also to say something briefly about the Indonesian fiction that was being written and published at the time, and how Indonesian Chinese writers of the time were relating to it. 
INDONESIAN FICTION OF THE FIFTIES AND THE POSITIONING OF CHINESE INDONESIAN WRITERS

Though the categorization of modern Indonesian literature has often been challenged by pointing out that individual writers straddle categories such as the Balai Pustaka (1920-1933), Pudjangga Baru (1933-1942) and the Angkatan 45 ('45 Generation', 1945-1966), there is some merit in retaining some of the observations that led to these conceptualizations. In particular the notion of a 45 Generation which was writing in a very different style, and using very different models, from those previously adopted in modern Indonesian literature can still be helpful, especially if taken in conjunction with historical circumstances of that period of twenty years between 1945-1965. In brief the critical points to note are that the well-known Indonesian writers of the time had come largely out of a background of Dutch-Western education and were therefore familiar with and attracted to European literature. Furthermore, they had also started to read modern American literature, often, but not always, in the Dutch translations that they had acquired serendipitously during the Japanese occupation when the contents of private Dutch libraries found their way into the street and when the public libraries of previously restricted access were made available to all (Watson 1972: 151-157). Consciously imitating the style of this fiction which was new to them, they began to write realist stories depicting contemporary political, social and economic circumstances as they existed in the major cities, and as they adversely affected the new urban proletariat. In this way they were purposively rejecting Indonesian literature of an earlier period ${ }^{6}$ which had emphasised romantic didactic plots and frequently centred upon the novelists' own class affiliations. A constant theme of this literature of the time was the disillusionment felt with the way in which things had turned out after Independence. All the promise and the hopes generated during the revolutionary period seemed to have been betrayed, and instead of the hoped-for new beginning, people were confronted by the sight of corrupt politicians exploiting opportunities for personal enrichment and allowing all those such as the veterans of the struggle against the Dutch to sink into poverty and oblivion.

This account, of course, generalizes wildly, and specialists will be able to point to numerous exceptions, yet I think all would agree that the short stories and novels of the late 40s and 50s are markedly different in character from their predecessors, and this is noticeable especially in the choice of subject for their writing, the attention paid to the accurate placing of characters in particular social settings, and their determination to portray the deteriorating conditions of the period through hard realistic description of the material conditions in which people were living, deliberately eschewing any kind of

\footnotetext{
6 One well-known instance of this conscious rejection is the publication of a poetry collection of three young writers, Chairil Anwar, Rivai Apin, and Asrul Sani, entitled Tiga menguak Takdir (1956), which can be translated as either 'Three push aside fate' or 'Three push aside Takdir', Takdir (Sutan Takdir Alisjahbana) being the name of one of the leading figures of an earlier period.
} 
romanticism or nostalgia.

This trend became particularly visible during the course of the 50s when political dividing lines were sharpened and writers chose to give expression to their views through the medium of fiction. Some of the realist writing, for example, took as its target the rampant corruption of the period and how it was affecting the common people who were suffering as a consequence. This comes out clearly in the fiction of Pramoedya, both in his short stories (Tjerita dari Djakarta 1957), his novellas (Midah, simanis bergigi emas 1954 and Gulat di Djakarta 1953) and novel (Korupsi 1954). But it is also there in the novels of Mochtar Lubis (Djalan tak ada udjung 1952) and, from a slightly later period, Sendja di Djakarta 1963) a writer who was extremely hostile to Pramoedya's views of the role of literature as a vehicle for politic action. ${ }^{7}$

In fact the pronounced public hostility between writers of different political persuasions gives that period its distinctive character. This is not the place to rehearse the polemics of the time ${ }^{8}$ and I simply mention it here in the first place to complement the description of historical context given above, but also because I want to point out that both camps in the polemics of the period, despite their disagreements, promoted their arguments through the same medium of realist fiction. Of course "popular" fiction continued to flourish with cheap editions of original and translated fiction, some romances, many detective stories, westerns, occasional translations of classical European literature offered between lurid covers, Emile Zola's novels, for example, but much of this popular literature too, especially in the form of short stories found in the magazines and literary journals of the time, adopted the same type of realism as more "highbrow" writing for the framing of their stories. To characterize briefly what readers would expect from this fiction one could say that the stories tended to be grim accounts of the economic hardships which many were facing and how this was leading both to the breakdown of social and family structures, and, on the political side, to increasing polarisation of social groups, and to escalating conflict and confrontation. Even those writers like Pramoedya who favoured Soviet-style socialist realism with its celebration and championing of the working classes and its purpose of encouraging optimism for the future were still writing depressing novels with bleak endings.

But where were the Chinese Indonesian writers in these turbulent times? Were they too caught up, like their political counterparts in the assimilationist and integrationist factionalism of the time, and did they, too, like their literary counterparts among the indigenous (asli [original] as they called them) give expression to their views through their fiction?

7 To my mind one of the best novels to describe that period which adopts the same conventions of social realism is Ramadhan KH's Royan revolusi. Published in 1971 but written earlier, it gives a graphic account of the politics of the time and the frustrations felt by many in society at the time.

8 Interested readers will find good coverage of the rivalries and disputes of the time in Foulcher (1969) and Foulcher (1986). Some fascinating autobiographical information about the personalities of the period is to be found in Ajip (2008: 315-322). 
In an informative article drawing on a close examination of the periodicals of the time Ulrich Kratz (1992) has helped us to answer these questions. Looking through issues of Star Weekly published between 1953-1963, in which it will be recalled contributions from Onghokham, Pramoedya, and KPH were all to be found, he identifies two important debates relating to literature and political identity. One concerns a discussion of whether Chinese Indonesian writers should now merge their identity into one of being Indonesian, albeit while still maintaining ethnic traits and traditions, or whether they should hold out for a separate identity altogether, since, it was argued they would never be accepted by the asli population. Parallels would be, I suppose, whether Black American writers should persist with a separate black American identity or see themselves as American tout court, and in English literature whether the category of Commonwealth writers is still salient. The other debate was about the quality and genre of writing which the Chinese Indonesian writers were or should be pursuing. Some argued, for instance, that the asli writers were far superior to Chinese Indonesian writers in relation to the themes, characters, and literary competence, and the latter were still writing fiction of the naïve romantic kind which had been so popular before the Pacific War and this needed to change. The milieu and background of the fiction, too, needed to be broader and not confine itself to the world of the Peranakan with asli individuals being relegated to roles as minor characters. Thus writers should publish not only in Peranakan outlets, but submit their work to the mainstream literary journals of the time. Others claimed that these criticisms were exaggerated, while seeming to recognize that Chinese Indonesians should be encouraged to write a more serious kind of fiction.

The first debate, the question of identity and the appropriateness of continuing to use labels such as sastra Melayu-Tionghoa, has been discussed by both Lombard and Salmon and Kratz reacting to Nio Joe Lan's statement in his book, Sastera Indonesia-Tionghoa (1962), that in fact the literature he describes there came to an end in 1942. Lombard and Salmon (2010) and Kratz (1992) give different arguments for saying that Nio Joe Lan was mistaken in his dating. Lombard and Salmon besides noting the continuing publication of short books serialized in weekly publications, looks in particular at the writing of Njoo Cheong Seng ${ }^{9}$ as reflected in his novella, Taufan gila, and other works of the 50s, also published in Star Weekly, and argues for more continuity than Nio Joe Lan allows, while at the same time noting that Njoo was writing in this novel about asli characters, in this case Makassarese. Kratz sees the stories in Star Weekly as the last examples of a tradition that was expiring before Phoenixlike resurrecting itself in an old genre given a new guise, the silat or kung fu stories of the errant knights of Chinese and, to a lesser extent, Javanese legend.

With respect to the debate about literary quality, target readerships and appropriate subjects and settings for fictional writing Kratz (1992: 137-145) notes the polemics in Star Weekly and Pantjawarna and provides some good illustrative quotations to indicate the strength of feeling of writers (and

9 For some fascinating biographical information about this author see Sidharta (2004: 23-51). 
editors) of the time. He does not, however, consider whether any writers did take up the challenge to write a more Indonesian and less Peranakan fiction. And although in the conclusion of his essay he mentions KPH by name, it is to point out that the latter, perhaps against the hopes of a senior generation, went on after the demise of Star Weekly in 1961 to make his name as a writer of silat fiction. That this was indeed what happened, no one would deny, but I want to show in what follows that things need not have turned out that way, and that there was a moment in which KPH was writing in the same language and style and taking the same issues in his short stories as his asli counterparts of the period, and that it was heightening tensions of the political events of the period which meant that this direction became a dead end both for him and other Peranakan writers. When Peranakan writers began to emerge once more in the 1970s it was a very different fiction they were writing, whether it was the new popular silat stories or the middle-class romances, both genres acceptable to the New Order government in a way in which social realism was not.

\section{Kho Ping Hoo's ReAList STORIES}

Like many Chinese Indonesians, KPH was directly caught up in the turbulence of the 50s and 60s. ${ }^{10}$ He had moved in 1950 to Tasikmalaya from Sragen in Central Java where, despite financial hardship, he had received a good education. The reason for his move is not clear but one may assume that he was offered a good employment opportunity. In Tasik he apparently became acquainted with totok Chinese and through them began to develop an interest in Chinese history and traditions. He also appears to have learned Sundanese well and also took courses in English. At the same time, although he was working in a transport company he seems to have wanted to pursue a career in writing, and sometime in the mid-50s he began to submit short stories to Star Weekly. When the 1955 law came into effect requiring Chinese Indonesians to opt for either Chinese or Indonesian citizenship he decided, presumably because of his growing interest in China and the influence of his totok friends, to opt for Chinese citizenship. And as pressure on Chinese citizens began to intensify he was one of those who opted for (re-)patriation to China in 1959. There were, however, logistical and bureaucratic obstacles in the way and he remained in Tasik and continued to contribute to Star Weekly and also to other Peranakan journals, including Pantjawarna and Liberty. In addition he seems to have set up a small publishing company, Djelita, in which he brought out short story collections including Pertemuan and his early silat stories. On the 10 May 1963, anti-Chinese rioting - frequently alleged to have been deliberately fomented by the military - broke out in Sukabumi (Selo Soemarjan 1964) and this was quickly followed by riots in other towns of West Java including Tasikmalaya. KPH was a victim of these riots; his house was burned and he lost some of his possessions including his printing press. Shortly after, because 
of his disappointment and the uncertainty of how affairs would develop, he returned to Solo in Central Java in 1964 and seems to have abandoned the kind of short story writing which he had pursued up till then, deciding to concentrate on the detective and silat stories which he had begun to try his hand at in 1960.

From what one can tell from the information in Sidharta (1994: 169-176) there does not seem to have been a clean break between writing stories about Indonesia and the new silat fiction, and for about four years, between 19601964, from what one can gather from the titles that Sidharta gives, he was writing both types of fiction, but after 1965, along with many asli writers of the period he steered away from social realism. The early stories, then, are very different from what came later and give an insight into what could have been a possible direction for Peranakan fiction which was never pursued. To indicate just how these stories chime with the mainstream realist writing of the time I want to discuss one of the stories, "Sosiawan besar" contained in Pertemuan. Unlike two of the other stories in the collection, it was not, as far as one can tell from Sidharta's list, published elsewhere. The other story not published elsewhere is "Riwajat 'Pak Ketjil" which in terms of its focus on the dispossessed is very similar in tone to the one described below.

\section{"SOSIAWAN BESAR" 11}

The title means 'The great philanthropist'. The word sosiawan is uncommon today, but has the same meaning, it would appear, as the common expression "berjiwa sosial" referring to someone with a social conscience. In this short story the title is ironic. The story itself introduced by KPH with the following sentence:

Dengan harapan semoga pada saat tjerita ini dibatja orang sosiawan2 seperti Pak Rangagung itu telah insaf dan dapat menjadi sosiawan sedjati sesuai dengan tjita2 rakjat dan kere2 hanja menjadi sebutan dalam dongeng belaka (p. 43).

(In the hope that when this story is read philanthropists such as Pak Rangagung will have recognised their faults and will have become genuine philanthropists of the kind hoped for by the people, and beggars will have become figures only known in stories of the past.)

Such an outright declaration of purpose is unusual as the introduction to a story, but it alerts readers to the critical realism that they should expect.

Told in a vivid, almost theatrical, fashion as though describing the stage setting of a one-act play in the present tense, the story begins by depicting a scene outside a restaurant. Beggars are assembled there, and one is bigger than the rest, his appearance described in graphic detail: thin as a rake, deep-sunken, expressionless eyes, filthy hands and nails, clothes in tatters, the only clean thing about him being the empty tin he uses for begging. He is 
not given a name; he is simply one of a crowd of beggars, all of them, except him, young boys. Also on the scene is a becak driver, Suparman, trying to find a fare, but constantly frustrated because would-be passengers are always trying to beat down the price he quotes. A paragraph relates his recent experiences. His wife has gone out of her mind because their son has recently died from illness after their make shift hut was flooded during the rains. Short, simple, unadorned sentences relate the succession of calamities without comment. "Rumah bilik-tua reot jang ketjil-ringan itu terbawa air dengan segala isinja jang tua bobrok. Anaknja mendjadi sakit dan mati seminggu jang lalu. Bininja seperti orang gila" (p. 44). He has had to take his wife back to her father's home in the village to people even poorer than himself. Now he is back in the town pedalling his becak again.

He watches the beggars scrambling for left-over food and then unexpectedly he gets a fare and moves off. A car drives up to the restaurant and three men step out; one, the principal figure, is obviously an important man and is flanked by two-hangers on. He is described as desiring to give the appearance of being important and struts (djalannja gagah) into the restaurant. He summons the driver of the car to come into the restaurant to join the meal, and smiles broadly at him, saying that they must all celebrate, and when the driver appears confused, he is told that they are celebrating the election of Pak Rangagung, the big man, - note that the name means exactly that to the position of Head of the Committee for a Healthy Society an ad hoc committee with no particular historical reference but of the kind that was frequently being set up at the time. The driver nods, but is still uncertain and asks whether he should join in and sit at the table with them, and is told of course: "Tentu boleh. Kita kan menudju masarakat adil dan makmur? [...] Kamu harus ikut" (p. 46). ("Aren't we working towards a just and prosperous society? [...] You have to join us [at the table]".) The driver nods again and says to himself: "Yes if only such justice was permanent".

They order mountains of food and while waiting they discuss the recent election and the two hangers-on flatter the big man, saying that great philanthropists are born not made and recognising that is what has made people vote for him. When the food is brought to the table the beggars outside look at them through the window. This disturbs the big man and he goes to express his anger at them since they are spoiling his meal. They run off, but the big man calls back the adult beggar introduced at the start of the story and questions him, accusing him of laziness and asking why he is not working. He tells him to go off threatening to put him in prison, to which the man replies: "In prison [...] are people given food?" (p. 4). And he is again told to be off or, says the big man, he will strike him. Going back to his meal the big man says to the others: "Anak ${ }^{2}$ matjam itu harus dibasmi dengan djalan kekerasan karena mereka itu sebenarnja bukannja tak dapat bekerja tapi adalah orang ${ }^{2}$ jang menderita penjakit malas" (p.48). ("People like that have to be wiped out by force because the truth is not that they can't get work but they are the kind of people who suffer from the disease of laziness".) They finish the meal and the big man 
makes a point of tipping the remains into the rubbish bin, rather than let the waiters distribute them to the waiting beggars. The big man and his entourage then go off again in the car, and as the big man drops the others off, he makes a point of telling them not to forget that they are to meet the next morning when they are to start collecting subscriptions for the victims of the flooding. The car drives off again at speed and when a becak drives crosses its path there is a collision and the becak driver is thrown violently to the ground. The big man's first reaction as he gets out of the car and sees the damage to the running board is to swear at the becak driver, calling him a "bangsat benar" (bloody idiot). But as people come crowding round to see what has happened his tone changes. He addresses the becak driver sympathetically asking if he is hurt, offering to take him to the hospital and giving him four one-hundred rupiah notes so that he can repair the becak. And as the man mutters his thanks, the big man Pak Rangagung looks round. "Mata Rangagung mengerling kilat dan tampak olenja berapa wadjah2 disekeliling tempat itu menatapnja dengan kagum" (p. 50). ("He looked round quickly and saw that the faces standing around there were looking at him with admiration".) Proud of himself he gets back into the car and drives away, and the story ends with him grumbling to himself. "Bangsat benar [...] empatratus amblas [...]" [p. 50]. ("Bloody idiot, four hundred down the drain".)

For readers familiar with Pramoedya's description of the urban poor in Jakarta at the time the story might well have come straight out of the collection, Tjerita dari Djakarta. We can see the same bitter irony, the same detailed depiction of the wretchedness of the urban poor and the same indifference to their plight by the wealthy observers who look down on the poor with contempt. At the same time the sardonic humour of the story, the mutterings of the driver, the question of whether those in prison receive food, point directly to the hypocrisy of political sloganeering - the concept of a "just and prosperous society" - voiced by those who exploit the situation for their own gain. The figure of the big man, the very name given to him, is emblematic of the ever-increasing gap between the haves and the have-nots and the injustice of the system which tolerates such a situation. Here it is not so much corruption which is at issue, though there is a hint of that too with the reference to the collection of charitable contributions, but the sheer unconscionable hypocrisy of the wealthy towards the poor.

The story, then, is very much like others of its kind being published at the time, both by those on the right and the left exposing the injustice of the time and critical of the current political system. In terms of the style of the story, the short descriptions of wretched physical appearance, so different from the romantic descriptions of the features of the heroines of pre-war fiction, there is nothing to indicate that the writer is a Peranakan. None of the characters are Peranakan. A sentence which indicates that one or two members of the association which Rangagung now heads are Chinese serves not to set the Chinese Indonesians as a group apart, but, on the contrary, to show how they are working with the asli majority. The language of the story, as the few 
quotations given above illustrate, is identical to that used in the mainstream literature of the time, no different to that found in the stories of, say, M. Balfas or Idrus or Utuy Sontani or Rukiah, all of whom, inspired by realist fiction, used short spare sentences to dramatic effect to highlight the awfulness of the scenes they were describing. Moreover, none of the vocabulary and sentence construction makes use of any specific Peranakan terms or syntax. In short, the story is of exactly that high standard reached by asli writers which so impressed the Peranakan critics who condemned the writers of their own community for the poor quality of the fiction they were producing at the time.

"Sosiawan besar" and "Riwajat 'Pak Kecil'" seem, however, to be among a handful of exceptions to the general trend of Peranakan fiction. More analytical research on the short stories of the period, following up on Kratz's useful catalogue, needs to be undertaken. And a search needs to be made for ephemeral publications, such as Pertemuan, published not in the major cities but in small towns such as Tasikmalaya. There may have been a lot more circulating at the time than we know about, although this seems unlikely, given the way in which writers sought out the well-known fiction magazines of the time as somewhere to place their stories.

One conclusion that we can draw from looking at this one example is, however, clear. Kho Ping Hoo had in the 50s developed a style of writing, which was noticeably mainstream, and not only that, but like several of the left-leaning writers of the time he was, through his fiction, making telling social criticisms of the existing situation. But at the very point when he might have chosen to develop his writing along these lines, political circumstances conspired against him. Not only was he personally the victim of anti-Chinese sentiment, but the magazines and journals in which he might have found space to publish such stories were closed down. In the circumstances, when he was trying to make a decent living for himself, it is no surprise that, since he found there was a market for his detective fiction and silat stories, he should abandon social realism for reasons of both economic and political security. ${ }^{12}$ As the example of "Sosiawan besar" demonstrates, the gain to the canon of silat literature came at the expense of what might have been an oeuvre of realist fiction to rival that of his asli contemporaries and which could have provided inspiration for a later generation of Peranakan writers. But perhaps it is too early to tell, and the present on-going rediscovery of Indonesian history of the 1950s and 1960s might yet lead others to take the road where Kho Ping Hoo hesitated but chose not to follow.

12 A reviewer of an earlier draft of this article has pointed out that with the growing antiChinese sentiment after 1959 which led to the demise of Star Weekly and to a ban on the publication of silat stories in serial form in newspapers in 1961 it might have been equally politically dangerous for $\mathrm{KPH}$ to have decided to write this latter type of story. However, it appears from the large number of publications from his hand from 1960 onwards that the authorities were unconcerned about these cheaply printed books. Such publications were not deemed, unlike Pramoedya's work on the overseas Chinese, to be critical of government policy. 


\section{REFERENCES}

Ajip Rosidi. 2008. Hidup tanpa ijazah: yang terekam dalam kenangan. Bandung: Pustaka Jaya.

Coppel, Charles. 1983. Indonesian Chinese in crisis. Kuala Lumpur/Oxford University Press.

Cushman, Jennifer W. and Wang Gungwu (eds). 1988. Changing identities of the Southeast Asian Chinese since World War II. Hong Kong: Hong Kong University Press.

Foulcher, K. 1969. “A survey of events surrounding Manikebu; The struggle for cultural and intellectual freedom in Indonesian literature", Bijdragen tot de Taal-, Land-en Volkenkunde 125: 429-465.

Foulcher, K. 1986. Social commitment in literature and the arts; The Indonesian "Institute of People's Culture" 1950-1965. Clayton, Victoria: Center of Southeast Asian Studies, Monash University.

Hong Liu. 2011. China and the shaping of Indonesia 1945-1965. Singapore: NUS Press.

Jahja, H. Junus. 2002. “Siauw Giok Tjhan 1914-1981; Terpeleset”, in: H. Junus Jahya, Peranakan idealis; Dari Lie Eng Hok sampai Teguh Karya, pp. 123-132. Jakarta: Kepustakaan Populer Gramedia.

Kratz, Ernst Ulrich. 1992. "Peranakan writing and Indonesian literature after independence", in: Claudine Salmon (ed.), Le Moment "sino-malais' de la littérature Indonésienne, pp. 133-147. Paris: Association Archipel. [Cahier d'Archipel No. 19.]

Lombard, Denys and Claudine Lombard-Salmon. 2010. "Di persilangan kesusastraan dan sejarah; Taufan Gila Karya Njoo Cheong Seng (1950)", in: Claudine Salmon, Sastra Indonesia awal; Kontribusi orang Tionghoa, pp. 506-522. Jakarta: Kepustakaan Populer Gramedia, EFEO, Forum Jakarta-Paris. [Originally published as "Au carrefour de la littérature et de l'histoire; Vent de folie de Njoo Cheong Seng (1950)", in: Sitti Faizah Soenoto (ed.). 1998, Persembahan; Studi in onore di luigi Santa Maria, pp. 185-202. Napoli: Istituto Universitario Orientale. Istituto Universitario Orientale, Dipartimento di Studi Asiatici, Series LIII.]

Nio Joe Lan. 1962. Sastera Indonesia-Tionghoa. Djakarta: Gunung Agung.

Onghokham. 1970. "The case for assimilation", in: H. Feith and Lance Castles (eds), Indonesian political thinking, 1945-1965, pp. 346-350. Ithaca, NY: Cornell University Press.

Pertemuan. (circa 1961). Kumpulan kisah pendek. Tasikmalaya: Djelita.

Pramoedya Ananta Toer. 1960. Hoa Kiau di Indonesia. Jakarta: Bintang Press.

Reeve, David, J.J. Rizal, and Wasmi Alhaziri (eds). 2007. Onze Ong; Onghokham dalam kenangan. Jakarta: Komunitas Bambu.

Salmon, Claudine. 1981. Literature in Malay by the Chinese of Indonesia. Paris: Association Archipel.

Salmon, Claudine (ed.). 1992. Le Moment "sino-malais" de la littérature Indonésienne. Paris: Asssociation Archipel. [Cahier d'Archipel No. 19.] 
Salmon, Claudine. 2010. Sastra Indonesia awal; kontribusi orang Tionghoa. Jakarta: École française d'Extrême-orient and Kepustakaan Populer Gramedia.

Selo Soemarjan. 1964. Gerakan 10 Mei 1963 di Sukabumi. Bandung: Eresco.

Siauw Giok Tjhan. 1981. Lima jaman; Perwujudan integrasi wajar. Jakarta/ Amsterdam: Teratai.

Siauw Giok Tjhan. 1982. A Peranakan-Chinese and the quest for Indonesian nation-hood. Edited by Bob Hering; with a foreword by Go Gien Tjwan. Townsville, Qld.: James Cook University of North Queensland.

Sidharta, Myra. 1994. "Asmaraman Sukowati Kho Ping Hoo (b. 1926); Writer of cloak-and-dagger stories in Indonesia", Archipel 48/1: 157-176.

Sidharta, Myra. 2004. Dari penjaja tekstil sampai superwoman; Biografi delapan penulis Peranakan. Jakarta: Kepustakaan Populer Gramedia.

Somers, Mary. 1964. Peranakan Chinese politics in Indonesia. Ithaca, NY: Southeast Asia Program, Departement of Asian Studies, Cornell University. [Interim Report Series - Modern Indonesian Project.]

Somers Heidhues, Mary. 1988. "Citizenship and identity; Ethnic Chinese and the Indonesian revolution", in: Jennifer W. Cushman and Wang Gungwu (eds), Changing identities of the Southeast Asian Chinese since World War II, pp. 115-138. Hong Kong: Hong Kong University Press.

Somers Heidhues, Mary. 2007. “Remembering Ong from the sixties”, in: David Reeve et al. (eds), Onze Ong; Onghokham dalam kenangan, pp. 231-235. Jakarta: Komunitas Bambu.

Suryadinata, Leo. 1983. "Liem Koen Hian Peranakan yang mencari identitas", Prisma 12/3: 71-85.

Thee Kian Wee. 2007. “Kawan lama saya Onghokham”, in: David Reeve et al. (eds), Onze Ong; Onghokham dalam kenangan, pp. 299-309. Jakarta: Komunitas Bambu.

Watson, C.W. 1972. "The sociology of the Indonesian novel 1920-1955”. MA thesis, University of Hull. 